
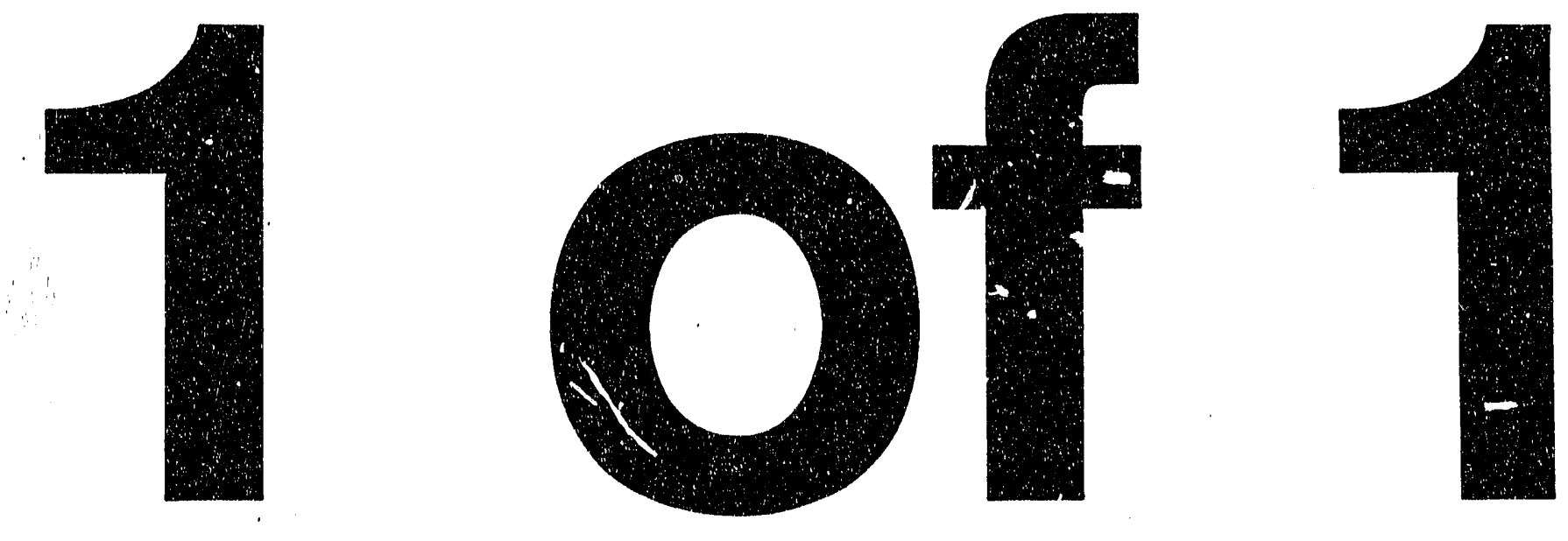
Prepared for the U.S. Department of Energy Office of Environmental Restoration and Waste Management

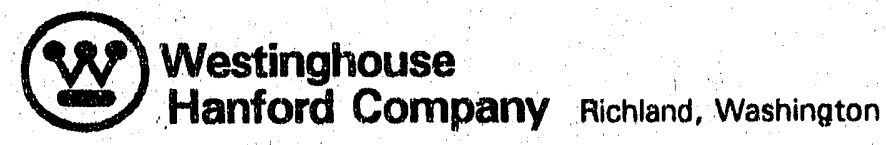

Hanford Operetions and Engineering Contractor for the 
LEGAL DISCLAMMER

This report was propared as an accourit of work sponsored by an agency of the United Stetes Government. Neither the

United States Government nor any agenoy thoreof, nor any of their employees, nor any of their. contrectors, subcontractors or their employees, makos eny warranty, oxpress or implied, or assumes any legal liablity or responsibility for the eocuracy, completeness, or any third party's use or the results of such use of any information, apparatus, product, or process disclosed, or represents that its use would not infringe privately owned rights. Reference herein to any epecifio oommercial product, process, or service by trade name, trademark, manufacturer, or otherwise, does not necessarily constitute or imply its endorsement, recommendation, or favoring by the United States Government or any agency thereof or its contrectors or subcontractors. The views and opinions of authors expressed herein do not necossarily stato or reflect those of the United States Government or any agency thereof.

This report has been reproduced from the best aveilable copy. Availabla in paper copy and miorofiche.

Available to the U.S. Department of Energy and its contractors from

Office of Scientific and Technical Information

P.O. Box 62

Oak Ridge, TN 3783 ?

(615) 578-8401

Printed in the Unitad States of Amerise

DISCLM-3.CHP (1-91) 


\title{
340 Facility Maintenance Implementation Plan
}

\author{
R. N. Wagner \\ E. J. Wright \\ Date Published \\ March 1995
}

Prepared for the U.S. Department of Energy Office of Environmental Restoration and Waste Management

$\begin{array}{ll}\text { Westinghouse } & \text { P.O Box } 1970 \\ \text { Hanford Company } & \text { Richland, Washington }\end{array}$

Hanford Operations and Enginearing Contractor for the

U.S. Department of Energy under Contract DE-AC06-87RL10930 


\section{RELEASE AUTHORIZATION}

Document Number: $\quad$ HC-SP-1154

Document Title: 340 FACILITY MAINTENANCE IMPLEMENTATION PLAN

Release Date: $\quad 3 / 29 / 95$

This document was reviewed following the procedures described in WHC-CM-3-4 and is:

APPROVED FOR PUBLIC RELEASE

WHC Information Release Administration Specialist:

Chis Ytilleighteaso

c. Willingham

$3 / 29 / 95$ 
WHC-SP-1154

Revision 0

340 FACILITY MAINTENANCE IMPLEMENTATION PLAN

March 1995

Prepared By:

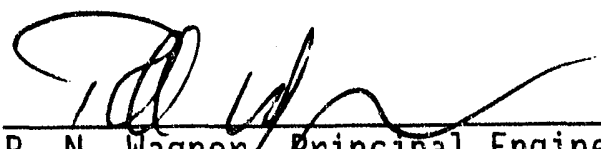

R. N. Wagner Principal Engineer West inghouse Hanford Company 300 firea Liquid Effluent Facilities

Maintenance and Work Control

Prepared By:

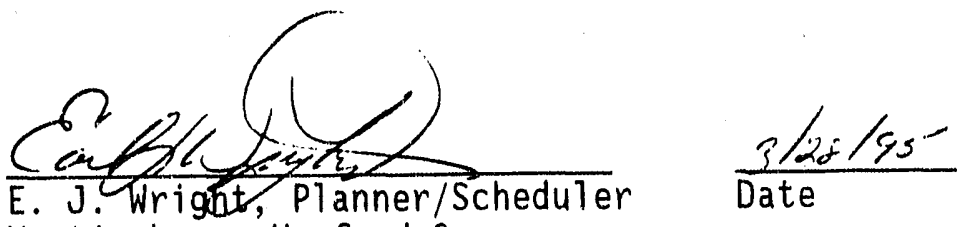
Westinghouse Hanford Company

300 Area Liquid Effluent Facilities

Maintenance and Work Control

Reviewed/Approved By:

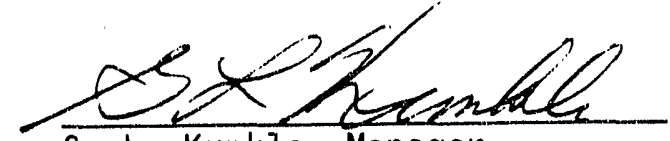

G. L. Kunkle, Manager

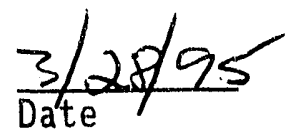

Westinghouse Hanford Company

300 Area Liquid Effluent Facilities

Maintenance and Work Control

Reviewed/Approved By:
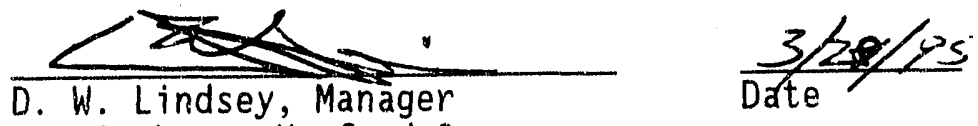
Westinghouse Hanford Company 300 Area Liquid Effluent Facilities

Reviewed/Approved By:
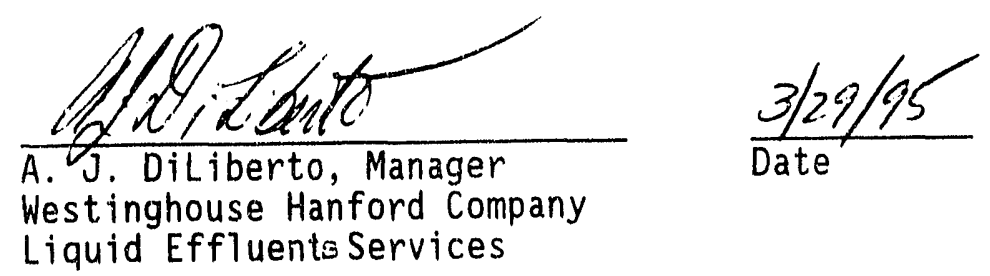
WHC-SP-1154

Revision 0

\section{FOREWORD}

This Maintenance Implementation Plan is written to satisfy the requirements of DOE Order 4330.4B, "MAINTENANCE MANAGEMENT PROGRAM," that specifies the general policy and objectives for the establishment of DOE controlled maintenance programs. These programs provide for the management and performance of cost-effective maintenance and repair of Department of Energy (DOE) property, which includes facilities.

A review of DOE Order 4330.4B, particularly Chapter II the nuclear portion, against existing WHC site programs and policies has provided assurance that most requirements of this order have already been implemented by existing WHC programs. Applicable requirements and guidelines of $4330.4 \mathrm{~B}$ that are deficient or not implemented are presently being developed and implemented through WHC site policies and programs. Where no program is presently identified or being developed for $4330.4 \mathrm{~B}$ requirements, responsibility for implementation has been assigned within this plan. 
WHC-SP-1154

Revision 0

TABLE OF CONTENTS

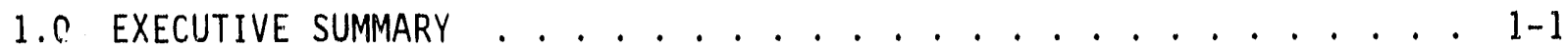

2.0 INTRODUCTION . . . . . . . . . . . . . . . . . . . 2-1

2.1 Facility Complex Description ............. 2-1

2.2 Mission ............. 2-1

2.3 History/Scheduled Life ................ . 2-2

3.0 DOE ORDER 4330.4B REQUIREMENTS .................. . . . . . . .

3.1 Maintenance Management Program Scope . . . . . . . . . . . . . 3-1

3.2 Maintenance Program Requirements . . . . . . . . . . . 3-1

3.3 Graded Approach Strategy . . . . . . . . . . . . . . . 3-2

3.3.1 Overall Strategy and Basis............ . 3-3

3.3.2 Strategy for Safety Related Items . . . . . . . . 3-3

4.0 DOE ORDER $4330.4 B$ CHAPTER II REQUIREMENTS . . . . . . . . . . 4-1

4.1 Evaluation of Compliance Elements . . . . . . . . . . . . . . . 4-1

4.2 Maintenance Organization and Administration . . . . . . . . . 4-1

4.2.1 Maintenance Organization Policies . . . . . . . . . . . 4-1

4.2.2 Maintenance Strategy............... . 4-2

4.2.3 Staffing Resources... . . . . . . . . . . . 4-3

4.2.4 Goals and Objectives......... . . . . . . 4-3

4.2.5 Accountability. . . . . . . . . . . . . . 4-4

4.3 Training and Qualification ............... 4-4

4.3.1 Responsibilities............... . . . 4-4

4.3.2 Maintenance Training Programs . . . . . . . . . 4-4

4.3.3 Training Schedules and Support . . . . . . . . . . 4-5

4.3.4 On-the-Job Training . . . . . . . . . . . . . 4-5

4.3.5 Qualifications ................ 4-5

4.3.6 Training in Root Cause Analysis . . . . . . . . . . 4-6

4.3.7 Training Program Approval, Effectiveness, and Feedback . 4-6

4.3.8 Management Training . . . . . . . . . . . . . 4-6

4.4 Maintenance Facilities, Equipment, and Tools . . . . . . 4-7

4.4.1 Facilities............... 4-7

4.4.2 Tool and Equipment Storage . . . . . . . . . . . 4-8

4.4 .3 Office Equipment .. . . . . . . . . . . . . . 4-9

4.5 Types of Maintenance .. . . . . . . . . . . . . . . 4-9

4.5.1 Master Equipment List . . . . . . . . . . . . . 4-9

4.5.2 Types of Maintenance . . . . . . . . . . . . . . 4-10

4.5.3 Maintenance Action and Frequency Selection ....... 4-11

4.5.4 Scheduling. . . . . . . . . . . . . . . . 4-11

4.6 Maintenance Procedures . . . . . . . . . . . . . . . . . 4-11

4.6.1 Procedure Development and Writing . . . . . . . . 4-12

4.6.2 Procedure Verification . . . . . . . . . . . . 4-12

4.6.4 Procedure Approva 1. . . . . . . . . . . . . . 4-13

4.6.5 Procedure Use . . . . . . . . . . . . . . . . . . 4-13

4.7 Planning, Scheduling, and Coordination of Maintenance . . . . 4-13

4.7.1 Planning for Maintenance Activities . . . . . . . . . 4-13

4.7.2 Scheduling Maintenance Activities . . . . . . . . . . 4-14 
4.7.3 Coordination of Maintenance Activities ........ . 4-15

4.7.4 Outage Planning, Scheduling, and Coordination . . . . 4-15

4.8 Control of Maintenance Activities........... . 4-15

4.8.1 Work Control Procedure . . . . . . . . . . . . . . 4-15

4.8.2 Work Request . . ............. 4-16

4.8.3 Supervision of Maintenance Activities . . . . . . . . 4-16

4.8.4 Review of Completed Work Requests . . . . . . . . . . 4-16

4.8.5 Temporary Repairs . . . . . . . . . . . . . . . . . . 4-17

4.8.6 Control of Nonfacility Contractor and Subcontractor

Personnel ................ . 4-17

4.9 Post-Maintenance Testing . . . . . . . . . . . . . 4-17

4.9.1 Post-Maintenance Test Requirements . . . . . . . . . . 4-18

4.9.2 Post-Maintenance Test Program Scope . . . . . . . . . . 4-18

4.9.3 Post-Maintenance Test Control . . . . . . . . . . . 4-18

4.9.4 Post-Maintenance Test Performance Documentation and

Acceptance .. . . . . . . . . . . . . . . 4-18

4.10 Procurement of Parts, Materials, and Services . . . . . . . 4-19

4.10.1 Procurement Policy and Procedures . . . . . . . . . . . 4-19

4.10.2 Procurement Initiation . . . . . . . . . . . . 4-19

4.10.3 Procurement Control. . . . . . . . . . . . . 4-20

4.10.4 Services . . . . . . . . . . . . . . . . . . 4-20

4.11 Material Receipt, Inspection, Handling, Storage, Retrieval, and Issuance ... . . . . . . . . . . . . . 4-21

4.11.1 Receipt and Inspection . . . . . . . . . . . . . 4-2i

4.11.2 Handling . . . . . . . . . . . . . . . . . . . . 4-21

4.11.3 Storage Material and Equipment . . . . . . . . . . 4-22

4.11.4 Retrieval and Issuance . . . . . . . . . . . . . . . 4-2?

4.12 Control and Calibration of Measuring and Test Equipment . . . 4-22

4.12.1 Identification . . . . . . . . . . . . . 4-22

4.12.2 Calibration .. . . . . . . . . . . . . 4-23

4.12.3 Control .................... . 4-24

4.12.4 Evaluation .. . . . . . . . . . . . . . . . 4-25

4.13 Maintenance Tools and Equipment Control . . . . . . . . . . 4-25

4.13.1 Storage and Issuance . . . . . . . . . . . . . . 4-25

4.13.2 Tool and Equipment Maintenance . . . . . . . . . . . 4-26

4.13.3 Use of Special Tools and Equipment . . . . . . . . . . 4-26

4.14 Facility Condition Inspection . . . . . . . . . . . . 4-26

4.14.1 Standards . . . . . . . . . . . . . . . 4-26

4.14.2 Training. . . . . . . . . . . . . . . . 4-27

4.14.3 Procedures . . . . . . . . . . . . . . . . 4-27

4.14.4 Scope of Inspections . . . . . . . . . . . . . . 4-27

4.14.5 Inspection Program Elements . . . . . . . . . . . . 4-28

4.14.6 Reporting Deficiencies . . . . . . . . . . . . . . . 4-28

4.14.7 Deficiency Follow-up .. . . . . . . . . . . . . . 4-28

4.15 Management Involvement . . . . . . . . . . . . . . 4-29

4.15.1 Management Involvement . . . . . . . . . . . . 4-29

4.15.2 Performance Indicators, Goals, and Objective Results . . 4-30

4.15.3 Feedback. . . . . . . . . . . . . . . . 4-30

4.15.4 Program Reviews . . . . . . . . . . . . . . . 4-30

4.16 Maintenance History . . . . . . . . . . . . . . . . . . . . 4-31

4.16.1 Program Development . . . . . . . . . . . . . . 4.31

4.16.2 Data Collection .............. . . 4-32 
4.16.3 Program Use ................... . 4-32

4.17 Analysis of Maintenance Problems . . . . . . . . . . 4-32

4.17.1 Information Collection ............. . 4-33

4.17.2 Event Analysis ........ . . . . . . . 4-33

4.17.3 Cause Determination .. . . . . . . . . . . 4-33

4.17.4 Corrective Action ................ . 4-33

4.17.5 Corrective Action Follow-up ........... . 4-34

4.17.6 Generic Follow-up . . . . . . . . . . . . . . 4-34

4.18 Modification Work . . . . . . . . . . . . . . . . . 4-34

4.18.1 Maintenance Program Interface with Modifications . . . 4-34

4.18.2 Temporary Repairs or Temporary Modifications . . . . 4-35

4.19 Additional Maintenance Management Requirements . . . . . . . 4-35

4.19.1 Seasonal Facility Preservation Requirements . . . . . 4-35

5.0 DEVIATIONS REQUESTED WITH SUPPORTING RATIONALE . . . . . . . . . . 5-1

6.0 IMPLEMENTATION SCHEDULE . . . . . . . . . . . . . . . . 6-1

7.0 BIBLIOGRAPHY . . . . . . . . . . . . . . . . . . . . . 7-1 


\section{LIST OF TERMS}

AMS Action Management System (Division-wide)

CTS

DOE Commitment Tracking System ( 300 Area Liquid Effluent Factlities)

DST

$H A_{T}^{T} S$ Department of Energy Double She 11 Tank Hanford Action Tracking System (Company-wide)

ICF-KH ICF-Kaiser Hanford South Pregrammatic Services

JCS Job Control System

LEF Liquici Effluent Facilities

LEPE Liquid Effluents Process Engineering

M\&TE Measuring and Test Equipment

MEL Master Equipment List

MIP

OJT

PIC

Maintenance Implementation Plan

On--the-Job Training

Person-In-Charge

$\mathrm{PM} / \mathrm{S} \quad$ Preventive Maintenance/Surveillance

PNL Battelle Pacific Northwest Laboratories

SAD Safety Assessment Document

SEL Safety Equipment List

WHC

Westinghouse Hanford Company 
WHC-SP-1154

Revision 0

\subsection{EXECUTIVE SUMMARY}

This Maintenance Implementation Plan (MIP) has been developed for maintenance functions associated with the 340 Facility. This pian is developed from the guidelines presented by Department of Energy (DOE) Order 4330.4B, Maintenance Management Program (DOE 1994), Chapter II.

The objective of this plan is to provide baseline information for establishing and identifying Westinghouse Hanford Company (WHC) conformance programs and policies applicable to implementation of DOE order $4330.4 \mathrm{~B}$ guidelines. In addition, this maintenance plan identifies the actions necessary to develop a cost-effective and efficient maintenance program at the 340 Facility.

Primary respon:ibility for the performance and oversight of maintenance activities at the 340 Facility resides with Westinghouse Hanford Company (WHC). Maintenance at the 340 Facility is performed by ICF-Kaiser Hanford (ICF-KH) South Programmatic Services crafts persons.

This 340 Facility MIP provides interface requirements and responsibilities as they apply specifically to the 340 Facility. This document provides an implementation schedule which has been developed for items considered to be deficient or in need of improvement.

The discussion sections, as applied to implementation at the 340 Facility, have been developed from a review of programs and practices utilizing the graded approach. Biennial review and additional reviews are conducted as significant programmatic and mission changes are made. This document is revised as necessary to maintain compliance with DOE requirements. 


\subsection{INTRODUCTION}

\subsection{Facility Complex Description}

The 340 Facility is located in the central portion of the 300 Area of DOE's Hanford Reservation. The 300 Area is a 400 acre section in the southeast corner on the west bank of the Columbia river, about six miles north of Richland, Washington.

The 340 Facility serves as a radioactive/mixed liquid waste handling facility servicing laboratories located in the 300 Area. The facility has the capability to accumulate, store and ship this waste. Waste is shipped via rail tankers to the double shell tanks (DSTs) located in the 200 Area Tank Farm Complexes.

The facility also provides radioactive monitoring for non-hazardous, potentially radioactive process sewer waste. The facility maintains diverter stations in several 300 Area laboratories. These diverter stations monitor for radioactivity and, if detected, the waste goes to tariks located at the 340 Facility. If not radioactively contaminated, the waste is transferred to the 300 . Area Process Sewer.

The Main facility consists of:

1. 340 Complex Buildings, including $340,340-A$ and $340-B$

2. 307 Basins

3. 340 Vault and Valve Pit.

The structures supporting the 340 Facility are:

1. Diverter Stations for Buildings $324,325,326,327$, and 329

2. 3707-F Sample Building

3. 340 Facility Support Facilities:
a. M0-741 (Health Physics)
b. M0-036 (Administrative Offices)
c. A covered slab for the storage of full and empty compressed gas bottles.

\subsection{Mission}

The 340 Facility Complex serves as a radioactive/mixed liquid waste handling facility servicing laboratories located in the 300 Area. The facility has the capability to accumulate, store and ship this waste. Waste is shipped via rail tankers to the DSTs in the 200 Area Tank Farm Complexes. 
The 340 Facility mission is to continue to support 300 Area WHC and Pacific Northwest Laboratories (PNL) by disposing of radioactive liquid waste into the foreseeable future.

\subsection{History/Scheduled Life}

The 340 Facility began operation in 1953 . The facility was upgraded in 1963 to include a railcar loadout facility used to fill 20,000-gallon railcars. In 1978-79, the underground piping used to transport waste from the laboratories to the 340 Facility was replaced with encased piping and a leak detection monitoring systeri was installed. In 1992-93, the process water system was upgraded. In 1994, the 340 Facility Stack and 307 Basin Collection systems were ingraded.

Long range planning is being provided for facility and equipment upgrades and modification to ensure compliance with future environmental and regulatory requirements as an ongoing process. The 340 Facility is expected to continue operations into the foreseeable future. 
WHC-SP-1154

Revision 0

\subsection{DOE ORDER 4330.4B REQUIREMENTS}

\subsection{Maintenance Management Program Scope}

The Maintenance Management Program for the 340 Facility encompasses a 11 facilities and auxiliary buildirgs associated with the 340 Facility. Maintenance activities associated with the 340 facility are provided by 300 Area Liquid Effluent Facilities (LEF) Work Control and ICF-KH. These activities, whether for building upkeep or for repair, calibration and/or rework of equipment, are performed by the 340 Facility maintenance organization.

\subsection{Maintenance Program Requirements}

System and component maintenance requirements are established based on analyses that consider safety clasifications, programmatic concerns; risk assessments of the facility, system, and component; requirements derived from OSD-SW-153-00001, Operating Specification Document for the 340 Waste Handling Facility, and operating experiences and maintenance history. They address the following DOE Order $4330.4 \mathrm{~B}$ requirements:

Requirement: (1) The structures, systems, and components included, using a graded approach and the requirements derived from Technical iafety Requirements.

Discussion:

OSD-SW-153-00001 defines operational safety requirements. The 340 Facility Safety Equipment List (SEL) defines the included structures, systems, and components.

Requirement: (2) The management systems used to control maintenance activities, including the means for monitoring and measuring the effectiveness of the program and the management of maintenance backlog.

Discussion:

340 Facility maintenance activities are managed and controlled in accordance with WHC-CM-1-8, Work Management Manua7. WHC-CM-1-8 includes means for monitoring and measuring program effectiveness and backlog management through the Job Control System $(J C S)$.

Requirement: (3) The assignment of responsibilities and authority ior all levels of the maintenance organization.

Discussion:

The 300 Area LEF Maintenance/Work Control Manager is responsible for maintaining a trained, qualified staff to support the maintenance needs of the 340 Facility. ICF-KH is matrixed to WHC to provide maintenance craft support; hence, the ICF-KH Maintenance Supervisor is responsible for assigning field work activities to a person-in-charge (PIC). 
Requirement: (4) Mechanisms for feedback of relevant information, such as trend analysis and instrumentation performance abid reliability data, to identify necessary program modifications.

Discussion:

Addressed in WHC-CM-1-8.

Requirement: (5) Provisions for identification, evaluation, and correction of possible component, system design, quality assurance, or other relevant problems.

Discussion:

Addressed in WHC-CM-1-8.

Requirement:

(6) Performance indicators and criteria to be utilized to measure equipment, systems, and personnel effectiveness in maintenance activities.

Discussion:

Addressed in WHC-CM-1-8.

Requirement:

(7) Interfaces between maintenance and other organizations (i.e., operations, engineering, quality, training, environment, safety, and health).

Discussion: Defined in WHC-IP-1000, 300 Area Liquid Effluent Facilities Administration.

Requirement: (8) A self assessment program to monitor the effectiveness and efficiency of the maintenance program.

Discussion:

A self assessment progran has been developed for 340 Facility maintenance. This self-assessment program is to be utilized at the 340 Facility on an as needed basis to evaluate the 340 Facility maintenance program. Assessments of the maintenance activities at the 340 Facility are performed when deemed appropriate, when major changes to maintenance policy and practice so warrants, or as required by the order (every two years).

Requirement: (9) Provisions for planning, scheduling, and coordination of maintenance activities.

Discussion: $\quad$ Addressed by WHC-CM-1-8. 


\subsection{Graded Approach Strategy}

"Graded Approach" is defined as the depth of detail required for implementatiun and the magnitude of resources expended for a particular maintenance management element.

\subsubsection{Overall Strategy and Basis}

A graded appriuch is used to identify the depth of detail and the level of commitiment required to ensure safe and reliable operations, environmental compliance, programmatic mission, and facility preservation. Personnel and pullic safety, availability of funding, operational safcty/reliability, environmental safety/rompliance, safeguards anc security, programmatic mission, and other facility specific requirements are to be considered when work is prioritized and performed.

At the 340 Facility, the SEL has been developed to provide designation and categorization of equipment and components as they apply to safe operation and shutdown of the facility. The SEL ensures all appropriate equipment has been identified. Maintenance activities initiated and proceaures developed as a result of the safety classification ensure appropriate levels of maintenance are applied.

\subsubsection{Strategy for Safety Related Items}

System and equipment safety classification and risk categories are assigned in accordance with established Westinghouse Hanford procedures and criteria. These categories support a graded approach to maintenance activities including assignment of level of review and approval, work control, procedural detail and requirements, documentation, historical records, oversight, and methods of verification and validation. The philosophy for work priority and allocation of resources dictates that correction of discrepancies having a direct impact on safety receives higher priority than non-safety related items or plant enhancements. 


\subsection{DOE ORDER 4330.4B CHAPTER II REQUIREMENTS}

\subsection{Evaluation of Compliance Elements}

The Hanford Site has existing programs and administrative guidelines providing for control and implementation of a maintenance program conforming to DOE Order 4330.4B. Maintenance activities at the 340 Facility are performed in accordance with these existing documents and procedures. This MIP correlates the DOE requirements to the existing 340 Facility maintenance program, and defines deviations and/or special program activities where appropriate.

\subsection{Maintenance Organization and Administration}

The organization and administration of the maintenance function ensures a high level of performance is achieved through effective implementation and control of maintenance activities. Facility policies reflect striving for excellence in facility maintenance and operation.

4.2 .1

objective:

Discussion:

\section{Maintenance Organization Policies}

To establish and communicate policies, procedures, and standards for the administration, implementation and control of maintenance activities.

The 300 Area LEF Manager is the 340 Facility Manager. This position is responsible for both maintenance and operational activities at the 340 Facility. The required maintenance activities are accomplished by the maintenance organization working through the 300 Area LEF Work Control Center.

The 300 Area LEF Operations Manager is the 340 Facility operations Manager. This position is responsible for prioritizing maintenance activities at the 340 Facility. A11 maintenance is performed per the requirements of maintenance guidelines, applicable site procedures, and the JCS program.

The 300 Area LEF Maintenance/Work Control Manager is the 340 Facility Maintenance Manager. This position provides the necessary interface with external organizations (ICF-KH and others) involved in maintenance activities at the 340 Facility.

The ICF-KH Maintenance Supervisor assigns field work to a PIC, who supervises the ICF-KH crafts workers performing 340 Facility maintenance. The ICF-KH Maintenance Supervisor coordinates any necessary ICF-KH support resources.

The 340 Facility maintenance program uses existing WHC and ICF-KH programs and policies, including the PIC concept. There is no need for additional policies at this time. The 
Maintenance Manager reviews the maintenance program and identifies program changes when necessary. Applicable documents are revised as additional requirements are identified.

Improvement: No improvement is needed at this time.

\section{2 .2}

Objective:

\section{Discussion: Working Relationships}

The 340 Facility Maintenance Manager coordinates interface activities between cross-discipline organizations as required for 340 Facility maintenance activities. The ICF-KH Maintenance Supervisor supervises the crafts maintenance activities.

Authority, responsibility, and accountability for support organizations is governed by WHC-IP-1000 as applicable to the maintenance organization.

Maintenance activities are controlled by 300 Area LEF Work Control and the JCS per site procedures. Prioritization and scheduling of maintenance activities is directed by the operations organization.

\section{Discussion: Long Range Planning}

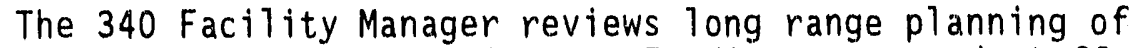
major maintenance activities. Funding scope and staff resources to meet the needs of the maintenance program are provided through budget requests.

The 340 Facility Maintenance Manager monitors staffing and resource requirements to assure 340 Facility maintenance tasks can be supported. If additional training is required to support a task, the Maintenance Manager allocates time for training. Crafts training is coordinated by the ICF-KH Maintenance Supervisor.

The Maintenance Manager reviews scheduling requirements of facility activities to ensure adequate staffing is available during periods of anticipated facility needs. Also the manager provides justification to higher management for additional personnel and training.

Improvement: No improvement is needed at this time. 
4.2 .3

objective:

Discussion:

Improvement: No improvement is needed at this time.

\section{Staffing Resources} incentive programs. procedures. Manager and the ICF-KH Maintenance Supervisor. appropriate resources are available.

To assemble and maintain a maintenance organization staff selected to prescribed qualification criteria commensurate with the facility mission(s), and maintaining the level of skill for maintenance personnel through training and Maintenance Supervisor screen personnel to ensure the skill level of work control personnel and craft persons is commensurate with the risk and complexity of the assigned activities. The 340 Facility Maintenance Manager and the ICF-KH Maintenance Supervisor provide for assessment of maintenance personnel in accordance with existing site

Qualifications for maintenance personnel are defined by existing site procedures, and ensure personnel are trained and capable of performing work at nuclear facilities. Periodic reviews of maintenance personnel training and performance are performed by the 340 Facility Maintenance

The 340 Facility Maintenance Manager and the ICF-KH Maintenance Supervisor review personnel performance and productivity to ensure qualified maintenance personnel are properly utilized. Training designed to assist deserving individuals in career progression assignments and activities is made available through existing WHC and ICF-KH training programs. If additional resources are required. the 340 Facility Maintenance Manager and/or ICF-KH Maintenance Supervisor adjust manpower so

\section{2 .4}

\section{Goals and otjecti'ses}

Objective: Establish maintenance goals to monitor maintenance activity progress, detect development of trands (favorable and unfavorable), improve performance, cr' ste a safe working envirnnment, and measure overall maintenance program effectiveness.

Discussion: Maintenance goals and objectives are defined for 300 Area LEF Work Control in WHC-IP-1000. The 340 Facility is committed to support the goals and objectives of the WHC and ICF-KH maintenance organizations. Specific goals for 300 Area LEF Work Control and performance indicators for continued monitoring are reviewed and updated monthly.

Improvement: No improvement is needed at this time. 
WHC-SP-1154

Revision 0

4.2 .5

Accountability

Objective: To monitor personnel in the performance of their assigned responsibilities and administer recognition or discipilinary actions as appropriate to individual performance.

Discussion: Existing site procedures provide for performance reviews and critiques of maintenance personnel. The 340 Facility Maintenance Manager and the ICF-KH Maintenance Supervisor perform this task annualiy, as a minimum.

Improvement: No improvement is needed at this time.

\subsection{Training and Qualification}

A maintenance training and qualification program consistent with DOE Orders $5480.5,5480.6,5480.20$, and $5480.18 \mathrm{~A}$ is established and controlled by WHC-CM-2-15, Training Administration Manual. The WHC Work Control and ICF-KH maintenance personnel are trained and qualified under the requirements specified in WHC-IP-1000, which incorporates site-mandated and facility-specific training requirements. Facility-specific ICF-KH training requirements are specified in Internal Memorandum 86710-94-LWR-013 dated March 8, 1994.

\section{3 .1}

\section{Responsibilities}

Objective: Establish a maintenance training program with a clear definition of requirements and responsibilities for development and implementation. Program development includes input from maintenance managers and supervisors and be closely coordinated with the training organizations.

Discussion: The responsibility for establishing, maintaining, and implementing the maintenance training programs is defined in WHC-CM-2-15 and WHC-IP-1000. The 300 Area LEF Operations Manager is responsible for coordinating the training program between the 340 Facility maintenance organization and the WHC training organization. This is accomplished in accordance with existing site procedures and WHC-CM-2-15.

Improvement: No improvement is needed at this time.

\section{3 .2}

\section{Maintenance Training Programs}

objective: Maintenance training programs should be defined and include courses for all functional aspects of the maintenance activity (e.g., management, planning, engineering, support functions).

Discussion: Maintenance training programs pertaining to managerial, supervisory, planner/scheduler, engineering, craft positions, contractor personne1, and other positions, as 
deemed necessary, are accomplished in accordance with WHC-CM-2-15, and WHC-IP-1000.

Improvement: No improvement is needed at this time.

\section{3 .3}

\section{Training Schedules and Support}

Objective: Training lessons are provided that are compatible with the individual's skills and abilities. Schedules are coordinated between maintenance managers and training organizations to ensure availability of instructors, facilities, and support requirements, as well as availability of trainees.

Discussion: The 300 Area LEF Operations Manager ensures training implementation is coordinated between the maintenance and the training organization, and the Training Coordinator to prepare training schedules, determine attendance, and ensure qualified instructors are available to teach the courses.

Qualification of instructors is controlled by WHC site training department in accordance with WHC-CM-2-15.

Improvement: No improvement is needed at this time.

\section{3 .4}

On-the-Job Training

Objective: Formal on-the-job (OJT) programs defining specific requirements for final qualification of personnel must be established. OJT training shall be conducted by qualified instructors in accordance with approved training plans.

Discussion: A formal OJT program exists. As equipment is identified for OJT, the ICF-KH Maintenance Supervisor ensures personnel satisfactorily complete OJT prior to being assigned work on that equipment.

Improvement: No improvement is needed at this time.

\section{3 .5}

\section{Qualifications}

Objective: Maintenance management shall review training records and verify all appropriate testing and/or interviews have been successfully completed prior to qualification of individuals for a given task.

Discussion: The 300 Area LEF Operations Manager and ICF-KH Maintenance Supervisor establish adequate records to verify qualificaicion standards and evaluation methods to guarantee trainee competence.

The 340 Facility Manager, ICF-KH Maintenance Supervisor, and the 300 Area LEF Operations Manager are directly 
involved in approving and periodically reviel . the maintenance training program.

Improvement: No improvement is needed at this time.

4.3 .6

Objective:

Discussion:

\section{3 .7}

Objective:

\section{Training in Root Cause Analysis}

An approprtate number of individuals are trained in principles and methods of root cause analys is and various approaches to cause and effect analysis. Individuals are able to support maintenance needs and schedules.

Representative WHC maintenance managers and others trained in the principles and the methods of root cause analys is are called upon to perform this service. When needed, chis team assembles and provides an independent determination of cause and effect. Personnel from other WHC organizations with the requisite training are called upon when necessary. Results are documented and a resolution is presented for further review.

Improvement: No improvement is needed at this time.

Training Program Approval, Effectiveness, and Feedback
Discussion: approval of the maintenance iraining program and training topic lesson plans. Performance of maintenance personnel is monitored for evaluation of training effectiveness, and personnel feedback is used in the effectiveness evaluation.
The 300 Area LEF Facility Manager maintains overall responsibility for personnel training and qualification. The 300 Area LEF Maintenance Manager is responsible for the review and approval of applicable training programs, the identification of training needs for the Maintenance and Work control organization, and reviewing existing training programs to ensure trainees develop the required skills and knowledge.

The maintenance manager participates in the review and

Improvement: No improvement is needed at this time.

4.3 .8

\section{Management Training}

Objective: A formalized program is in place to develop and maintain management and supervisory skills. Training provided addresses topics (e.g., personnel interfacing, communications, assessments) necessary for effective management and team building. The training program considers support of career progression for entering the management field.

Discussion: The training department provides management and supervisory training including generic areas such as managerial skills, 
accountablitty, assessment and observation of routine activities, communication skills, teamwork, and company management philosophies. "Position-specific training is provided to first-line managers. All training is conducted in accordance with WHC-CM-2-15 and other existing site procedures.

Improvement: No improvement is needed at this time.

\subsection{Maintenance Facilities, Equipment, and Tools}

Maintenance facilities, equipmunt, and tools efficiently support facility maintenance and maintenance training.

\section{4 .1}

Objective:

\section{Discussion:}

\section{Facilities}

Shop facilities are designed with a high consideration of industrlal safety and convenience to the activities they support. Appropriate environmental control systems are provided, adequate support equipment, storage and 1ay-down areas are avallable, and controls are in place for factlity use.

\section{Shops and Satellite Work Areas}

The maintenance area for 340 Facility maintenance activities is provided at the 328 Building, operated by ICF-KH. This area is equipped with electrical power and pneumatic supplies for bench testing and troubleshooting. The shop is multi-disciplined and supports all maintenance personnel. Storage is provided in this work area for tools and test equipment. Specialized tools and test equipment are located in the shop unless size limitations require external facilities or areas. Crafts personnel use trucks equipped with tool boxes when working field assignments. The 340 Facility Maintenance Manager and the ICF-KH Maintenance Supervisor assess shop size and, if needed, additional space can be provided by satellite buildings or in other areas.

The ICF-KH Maintenance Supervisor is responsible for assuring shop lajout and design is conducive to a safe and efficient working environment.

The amount and type of work being performed in the shop area is normal day-to-day repair and servicing. Any specialized work requiring additional environmental controls (e.g., spectalty welding, machining, high voltage, radiation control, etc.) is performed at specific designated areas. The 340 Facility Maintenance Manager and the ICF-K.H Maintenance Supervisor assess work and determine where and under what controls the work is to be performed. Additional satellite work areas and stations can be provided if a need is determined and funding is available. 
WHC-SP-1154

Revision 0

Discussion: Lay-down and Staging Area

Lay-down and staging areas are provided at the 340 Facility If a need for these areas becomes apparent. These areas are zegregated according to radiological controls, hazardous materials, application, security requirements, and any other considerations. All areas are clearly marked and administratively controli:d.

Discussion: Storage Facllities

Storage for supplies and parts is provided on the factlity grounds and at the 328 Butlding.

Spectalized storage for radiological control is identifted and controlled through HSRCM-1, Hanford site Radiological Control Manual, and other existing site requirements and procedures.

Storage of flammable and hazardous materials is performed in accordance with WHC-CM-4-3, Industrial Safety Manual, and other existing site procedures.

Discussion: Temporary Facilities

No temporary factlities are in use at this time, but may be provided on an as-needed basis.

Discussion Decontamination Facilities

Decontamination of equipment, and tools, is performed on an as-needed basis. All contaminated equipment and tools are controlled by HSRCM-1.

Improvement: No improvement is needed at this time.

\section{4 .2}

Objective:

Tool and Equipment Storage

Storage factlities are in appropriate proximity to shops and work areas to support maintenance effictency. Appropriate environmental controls are in place for personnel and equipment protection.

Discussion: Adequate tool and equipment storage is provided by ICF-KH. Special tool and equipment storage has been identified. The 340 Factlity Maintenance Manager and the ICF-KH Maintenance Supervisor will address additional storage space if such a need arises.

Improvement: No improvement is needed at this time. 
Objective: Off:ise equipment necessary to support an efficient maintenance program is available (e.g., furniture, computers, communications, reproduction).

Discussion: Adequate communication, calculation, reproduction, and other office equipment is provided by WHC at the 340 Facility and by ICF-KH at the 328 Buliding.

Information Resources Management ensures adequate terminal, interface hardware, local area network systems, and file server requirements are provided at 340 Facility and 328 Building.

Improvement: No improvement is needed at this time.

\subsection{Types of Maintenance}

A proper balance of corrective and preventative maintenance should be employed to provide a high degree of confidence faclitity equipment. degradation is identified and corrected, that equipment life is optimized, and the maintenance program is cost effective.

\subsubsection{Master Equipment List,}

Objective: Develop (and maintain) a Master Equipment List (MEL) for use in identifying equipment safety classifications and maintenance program scope, and development of the equipment history file.

Discussion: The 340 Facility SEL, WHC-SD-WM-SEL-016, includes both safety-related and non-safety-related equipment, components and structures. The SEI has been developed from SD-WM-TM-001, Safety Asses nent Document for the 340 Waste Handling Facility (SAD), and other design documents, and is included in the 340 Facility maintenance program. Special tools and equipment are included in the SEL, as required. The cog engineer reviews any additions to the SEL and controls additions through the ECN program.

The 340 Facility is in the process of developing a MEL. The component file of the JCS system serves as the 340 Facility MEL. As components not already entered into JCS are identified for corrective or preventive maintenance, the cognizant engineers are responsible to add the components to the component file.

Improvement: Development of the 340 Factlity MEL contained in JCS is an on-going process (using graded approach). 340 Facility cog engineers are responsible for MEL development. 


\section{5 .2}

Objective:

\section{Discussion: Corrective Maintenance}

ICF-KH maintenance personnel perform corrective maintenance activities in accordance with existing site procedures and the administrative guidelines of WHC-IP-1000. Corrective maintenance is documented and controlled in accordance with WHC-CM-1-8. Feedback to the cog engineer is through the JCS program and maintenance supervision. The cog engineer evaluates the corrective maintenance program for effectiveness and changes it where necessary.

\section{Discussion: Preventive Maintenance}

The 340 Facility Maintenance Manager implements an effective preventive maintenance program including systems and equipment affecting safe and reliable facility operation. As part of the maintenance survelliance program, the Maintenance Manager ensures functional tests of installed equipment and/or systems (such as standby equipment or non-operating equipment scheduled for rotation) are conducted and documented. This is performed as part of post-maintenance testing actilities and documented on the JCS.

Preventive maintenance is performed at predetermined and scheduled intervals, as prescribed by the cog engineer, and seeks to maximize equipment availability. Preventive maintenance documentation provides a record of activities performed, data collected, and, where appropriate, the "as-found" and "as-ieft" condition of the equipment, and supplies this information to the JCS.

\section{Discussion: Predictive Maintenance}

The predictive maintenance program at the 340 Facility is 1 imited to reviews of operating and maintenance data by cog engineers. Using a graded approach, additional predictive maintenance measures are not cost effective at the 340 Facility due to its relative simplicity and lack of critical equipment.

Improvement: No improvement is needed at this time. 
4.5 .3

Objective:

Discussion:

Discussion:

\section{Maintenance Action and Frequency Selection}

Maintenance frequencies are established to satisfy code and specification requirements, and to ensure optimum equipment operating life and performance.

The cog engineer reviews 340 Facility equipment history periodically to ensure preventive maintenance/surveillance (PM/S) activities and their frequencies are used to inprove equipment performance while minimizing overall cost.

The 340 Facility Maintenance Manager evaluates maintenance actions and their frequencies to ensure code and regulatory requirements are being met.

The preventive maintenance program is modified as necessary from review and analys is of historical data by the 340 Facility Maintenance Manager and the cog engineers. This ensures the maintenance program is cost effective and required maintenance intervals are adequate. This strategy takes into account optimizing equipment life with overall maintenance costs. Any charge to the maintenance program is documented.

Improvement: No improvement is needed at this time.

\section{5 .4}

objective:

\section{Scheduling}

Preventive maintenance activities are scheduled according to assigned frequencies and in conjunction with coirective maintenance of the same equipment or with other activities related to equipment.

Discussion: The 340 Facility Maintenance Manager and cog engineers review the JCS periodically to determine if a proper balance of preventive to corrective maintenance activities is being achieved. This review determines when it may be advantageous to perform maintenance activities on related equipment, loop components, or on equipment in close proximity. This ensures equipment maintenance is optimized, productivity is increased, and facility down time is minimized.

Improvement: No improvement is needed at this time.

\subsection{Maintenance Procedures}

Maintenance procedures and other work-related documents (e.g., drawings and instructions) are prepared and used to provide appropriate work direction and to ensure that maintenance is performed safely and efficiently. A balance of written guidance, craftsman's skills, and work-site supervision (graded approach) is required to achieve the quality workmanship essential to safe and reliable facility operation. 
WHC-SP-1154

Revision 0

4.6 .1

Objective:

Discussion:

4.6 .2

Objective:

Discussion:

LEPE are technically verified and receive a final

administrative review in accordance with WHC-CM-3-5 and

WHC-IP-1000. WHC-CM-3-5 is used to determine the necessary

Approval Designator.

Improvement: No improvement is needed at this time.

\section{6 .3}

objective:

\section{Procedure Validation}

Procedures are reviewed for usability and correctness to ensure sufficient and understandable instructions are provided and are compatible to the equipment and task specified.

Discussion: The 300 Area LEPE Manager ensures al1 procedures developed by LEPE are validated in accordance with WHC-IP-1000.

Improvement: No improvement is needed at this time. 
4.6 .4

Objective:

Discussion:

Procedure Approval

Procedures are reviewed to applicable specifications and administrative procedures and approved by appropriate levels of management.

Discussion:

The 300 Area LEPE Manager ensures a11 procedures developed by LEPE are approved in accordance with WHC-CM-3-5 and WHC-IP-1000.

Improvement: No improvement is needed at this time.

\section{6 .5}

Objective:

Discussion:

\section{Procedure Use}

Procedure control is established ensuring availability and currency of the procedures to be used. Procedure compliance requirements are clearly stated, communicated, and understood by users.
The 340 Facility Maintenance Manager and the JCS ensure procedures used in the field are the most current and correct revision for use.

340 Facility management uses a graded approach when addressing the need for work procedures, in accordance with WHC-IP-1000 requirements.

Improvement: No improvement is needed at this time.

\subsection{Planning, Scheduling, and Coordination of Maintenance}

An effective system for planning, scheduling, and coordinating maintenance activities are implemented in order to ensure that maintenance is accomplished in a timely manner, improve maintenance efficiency, reduce radiation exposure, and increase equipment availability.

\section{7 .1}

Objective:

\section{Planning for Maintenance Activities}

\section{Establish a planning program that provides work} instructions, identifies resource requirements, and coordinates support functions.

\section{Discussion: Planning Group Organization}

All planning activities for the 340 Facility are performed by the 300 Area LEF Maintenance and Work Control (M\&WC) group utilizing the JCS in accordance with WHC-CM-1-8. 


\section{Discussion: Planning Group Responsibilities}

The 340 Facility Maintenance Manager is responsible for all planning activities at 340 Facility in accordance with existing site procedures.

Improvement: No improvement is needed at this time.

\section{7 .2}

\section{Scheduling Maintenance Activities}

Objective: A work control system should provide a means for tracking valid work requests, including identification, status, completion, post-maintenance testing and post-review. Preventive and corrective maintenance activities should be scheduled based on equipment similarity or proximity. Input from all affected organizations should be utilized for short-range and long-range preventive maintenance schedules. Work requests should be reviewed by operations to determine facility impact and meaningful priorities established.

\section{Discussion: Control of Work Backiog}

The 340 Facility Maintenance Manager expedites work packages to assure work is performed on schedule. Work backlog is tracked and controlled within the JCS in accordance with the requirements of WHC-CM-1-8. The 340 Facility Operations Manager is responsible for reviewing the backlog for work status and problem areas. The scheduling of work packages and work activities is performed through the JCS, the 340 Facility Maintenance Manager, and the 340 Facility Operations Manager.

The 340 Facility JCS activities are performed in accordance with applicable sections of WHC-CM-1-8 and WHC-IP-100D.

\section{Discussion: Work Priority}

The 340 Facility Operations Manager assigns work priorities on the basis of safety and operational requirements, using the graded approach. Assignment of work priorities is controlled by requirements of WHC-CM-1-8 and WHC-IP-1000.

The plan-of-the-week and plan-of-the-day meetings are used for integrating work priorities with the long range schedule.

Improvement: No improvement is needed at this time. 
WHC-SP-1154

Revision 0

\section{7 .3}

Objective:

Discussion:

Improvement: No improvement is needed at this time.

\section{7 .4}

Objective:

Discussion:

\section{Outage Planning, Scheduling, and Coordination} activities are performed in cooperation and coordination with other organizations.

Coordinate mainterance activities to ensure tint work can be effectively accomplished.

Routine planning meetings are held to ensure coordination

Establish program for identifying all maintenance activities to be performed during a definfd facility or equipment outage and develop schedule for planning and performance of those activities.

Facility outage planning is not applicable to the 340 provides the necessary direction to assure all maintenance Facility as there are no regularly scheduled outages at the facility. In the event of an unplanned outage, the Operations, Maintenance, and Engineering organizations may identify supplemental backlog work to be performed during the outage. In the event of an equipment outage or major evolution, backlog work packages and upcoming preventive maintenance activities are reviewed. Work items are identified to be accomplished in conjunction with the equipment outage, reducing and elimirating the need for additional outages.

Improvement: No improvement is needed at this time.

\subsection{Control of Maintenance Activities}

Management directed and delegated involvement in control of maintenance activities ensure maintenance practices are effective in maintaining safe, efficient, and reliable faciitity operation.

\section{8 .1}

Objective:

\section{Work Control Procedure}

Work control is accomplished in accordance with a formal program which defines the requirements and controls for performing work. The program is used to identify all facility deficiencies, modifications, preventive maintenance and surveillance testing, avoid redundant identification of deficiencies, and post-maintenance activities. 
Discussion: WHC-CM-1-8 is the admiristrative procedure describing work control requiremerits. Additional work control requirements are provided for in WHC-IP-1000.

Improvement: No improvement is needed at this time.

\section{8 .2}

\section{Work Requast}

objective:

A11 maintenance activities performed are controlled by the facility work control program. Work request documents clearly define work to be performed. equipment on which work is to be performed, pre (and post) requisites, and documentation requirements. Work requests are reviewed by affected organizations before release for work and upon completion of work.

Discussion: The work request process is controlled through the JCS program in accordance with WHC-CM-1-8.

Work requests are reviewed in accordance with requirements of WHC-CM-1-8 and WHC-IP-1000.

Improvement: No improvement is needed at this time.

\section{8 .3}

\section{Supervision of Maintenance Activities}

Objective: Maintenance managers routinely rionitor work in progress to ensure maintenance activities are conducted in accordance with facility procedures and work package instructions. Problems observed are analyzed and feedback is provided to prevent recurrence.

Discussion: The 340 Facility Maintenance Marager and the ICF-KH Maintenance Superviscr routinely monitor work in progress. The 340 Facility utilizes the PIC concept for maintenance activities where direct supervision of the work by non-maintenance personnel (eg., cog engineers) is desirable. This ensures maintenance activities are conducted in accordance with DOE and site policies and procedures, per approved job descriptions, WHC-IP-1000, and standard industry practice.

Improvement: No improvement is needed at this time.

\section{8 .4}

\section{Review of Completed Work Requests}

Objective: Completed work packages are reviewed to verify all work items, including post-maintenance testing and inspections, have been completed in an acceptable manner before returning system or equipment to service.

Discussion: When maintenance work is performed, the 340 Facility Operations Managers compare the work performed to the post-maintenance testing or inspection result to determine 
all work is acceptable prior to returning the equipment or system to normal service.

The cog engineer, Operations or Maintenance Manager may request post-maintenance testing in addition to post-maintenance tests already specified on the work package, if the scope of the work performed deems additional retesting.

The cog engineer recomminds closure of the work package after review.

Improvement: No improvement is needed at this time.

\section{8 .5}

Objective:

Discussion:

Improvement:

\section{8 .6}

Objective:

Discussion:

\section{Control of Nonfacility Contractor and Subcontractor Personnel}

Nonfacility contract and subcontract personnel who perform maintenance or modification work on 340 Facility systems are qualified for the work performed and trained in accordance with access requirements.

Site procedures provide for access control and general employee training of contractor and subcontractor personnel. The 340 Facility operations organization assures any additional training required for contractor or subcontractor personnel is performed and documented in accordance with site procedure. Qualification of contractor personnel is certified by the contractor; and verified and documented by the cog engineer before commencement of work activities.

Improvement: No improvement is needed at this time.

\subsection{Post-Maintenance Testing}

Post-maintenance testing is performed to verify components can fulfill their design function when returned to service after maintenance. 


\section{9 .1}

Objective:

Discussion:

-maintenance testing is conducted in accordance with WHC-CM-1-8 when maintenance work has been performed and when specified by the $\mathrm{cog}$ engineer or Operations. Most repair work performed at the 340 Facllity does not require any post-maintenance testing cther than an operability test, as applicable.

Improvement: No improvement is needed at this time.

\section{9 .2}

Objective:

Discussion:

Improvement :

\section{9 .3}

objective:

Discussion:

\section{Post-Maintenance Test Program Scope}

All maintenance activities are reviewed for applicability of post-maintenance testing and appropriate testing instructions (and acceptance criteria) are provided.

Post-maintenance testing at the 340 Facility is performed when the work instructions specify the requirement.

No improvement is needed at this time.

\section{Post-Maintenance Test Control}

The work control program addresses control of post-maintenance testing that covers all conditions of single or multiple organization involvement and testing that is deferred until a later date.

During work package closeout and review, retesting may be specified by operations or engineering before work package completion. If the retest can not be performed immediately and needs to be tracked, 300 Area LEF Work Control will status and track the retest requirement per WHC-CM-1-8.

Improvement: No improvement is needed at this time.

\section{9 .4}

Objective: Post-maintenance testing is performed in accordance with approved work package instructions (or preventive maintenance procedure) and completion is documented.

Discussion: The JCS is used for documenting post-maintenance testing instructions unless specific test requirements are identified. Documentation is performed in accordance with work package closeout and WHC-CM-1-8 requirements. Test 
results are documented and retained as part of the maintenance history.

Upon completion, the work package is reviewed for completion in accordance with WHC-CM-1-8 before approval.

Improvement: No improvement is needed at this time.

\subsection{Procurement of Parts, Materials, and Services}

Controls and assessment of procurement activities are used to help ensure that proper parts, materials, and services are purchased to support maintenance activities and to meet the requirements for safe and relitable factlitiy operation.

4.10.1

Objective:

Discussion: procurement of parts and material on a high priority basis when needed, as specified in WHC-CM-6-1 and WHC-CM-2-1, Procurement Manual and Procedures. WHC-CM-2-2, Materials Management Manua7, prescribes methods to acquire replacement parts not avallable through the original supplier.

The 300 Area LEF Work Control Procurement Specialist is responsible for procurement of parts and materials associated with 340 Facllity maintenance activities, as specified by job planners and/or the cog engineer. The ICF-KH Maintenance Supervisor is responstble for procuring parts associated with shop activities and equipment.

Equipment specified in the SEL is assessed for spare parts requirements by cog engineers. Recommended spare parts are procured in accordance with applicable site procedures.

Improvement: No improvement is needed at this time.

4.10 .2

objective:

\section{Procurement Initiation}

Procurement activities are conducted in a timely fashion. The procurement program addresses the pre-selection and qualification of procurement sources, spare parts inventory, and cross facility use of inventories.

Discussion: Lessons learned from experience, such as lead times, parts usage, and supplier reliability, are factored into 
materials management and included in existing site procedures.

Topics such as storage, in-storage preventive ma,intenance, and shelf-1ife requirements are addressed in WHC-CM-2-2.

Warehouse and procurement activities such as inventary, rotation, and other warehouse functions are specificaliy address in existing site procedures.

Improvement: No improvement is needed at this time.

\subsection{0 .3}

Objective:

Discussion:

\section{Procurement Control}

The procurement program provides for documentation and controls applicable to obtaining parts, materials, equipment, and services in accordance with the technical and quality requitrements.

\section{The cog engineer approves any deviation from design} specifications for parts or matertals.

Warehouse personnel review material and parts activity to determine possible new additions to be included in spare parts or site stores catalog.

Procurement documents per WHC-CM-2-1 provide clear and adequate technical and quality assurance requirements consistent with design specifications and safety classifications.

Deficient or nonconforming items are resolved in an effective and timely manner as specified by site procedures.

Quality assurance records are controlled and maintained per WHC-CM-3-5 and WHC-CM-4-2, Quality Assurance Manual, to provide documentation for qualified parts and matertals and to ensure traceability. The QA department performs audits, inspections or survelllances of suppliers according to $Q A$ requirements.

Improvement: No improvement is needed at this time.

\subsection{0 .4}

\section{Services}

Objective:

A program for selection and procurement of service contracts is in place and a renewal process may be initiated to prevent periods of non-coverage. Service contracts include provisions for emergency or short notice support.

Discussion: Identification of the need for spectalized services from vendors is made by the 340 Facility Maintenance and 
Engineering Managers to provide for timely submittal of bldding on, and awarding of contracts. This area is addressed in extsting procedures and impact on 340 Faciltty is addressed as requitred.

Improvement: No improvement is needed at this time.

4.11 Material Recelpt, Inspection, Handling, Storage, Retrieval, and Iss'dance

Al1 phases of receiving, inspecting, handling, storing, retrieving, and issuing equipment, parts, and materials for maintenance are covered by effectively implemented polictes and procedures consistent with the Quality Assurance Requirements of the factlity.

4.11 .1

Objective:

Discussion:

Receipt and Inspection

Receipt inspections of materials and equipment is performed before acceptance for use or storage verifying items delivered conform to all procurement document requitrements and are in good condition.

WHC-CM-2-1 arld WHC-CM-2-2 are prepared to speciffcally describe the responstbilities and techniques for receiving, inspecting, handling, storing, retrieving, and issuing equipment, parts, and materials.

Material is inspected per the requirements of WHC-CM-2-2 to ensure conformance to purchasing requirements prior to release for use and storage. Site procedures control documentation for received material and assures that these documents are accounted for and retrievable.

WHC-CM-4-2 speciftes nonconforming items are tdentified with tags or labels and controlled to prevent unauthorized use.

Improvement: No improvement is needed at this time.

\subsection{1 .2}

objective:

\section{Handling}

Procedures are provided for items requiring special handling. Procedures include all information necessary to prevent damage.

Discussion: WHC site procedures/instructions are avallable for t tems requiring special handling. Effective material procurement status is provided, including accurate stock records and tracking of purchase orders.

Improvement: No improvement is needed at this time. 
WHC-SP-1154

Revision 0

4.11 .3

objective:

Discussion:

Improvement: No improvement is needed at this time.

\subsection{1 .4}

Objective:

Discussion:

\section{Retrieval and Issuance}

A shelf-11fe control program per WHC-CM-2-2 is provided for store thems important to safe and reliable facility operation. Safety-related and non-safety-related materials and equipment are segregated from each other to prevent inadvertent use of the wrong category of item.

The quality of stored equipment, parts, and materials is maintained in accordance with vendor information by appropriate means, such as environmental and shelf-life controls and preventive maintenance activities, if necessary.

Parts, matertals, and equipment removed from storage are handled to the same requirements applied at time of receipt. A stores inventory system is in place to identify avallable materials and equipment and is available to using organizations, such as planning and engineering.

Parts and materials issued for installation are properly controlled per existing site procedures. Unused parts and matertals are promptly returned to a controlled storage area. Completed work requests document required material traceability.

Improvement: No improvement is needed at this time.

\subsection{Control and Calibration of Measuring and Test Equipment}

The program for control and calibration of measuring and test equipment (M\&TE) are consistent with the Quality Assurance requirements of DOE $5700.6 \mathrm{C}$ and ensure the accurate performance of facility instrumentation and equipment for testing, calibration, and repairs.

4.12 .1

Objective:

\section{Identification}

Establish a program for the assignment of a unique identification number for each item of M\&TE which is permanently marked or attached to the equipment and a 
Discussion:

Improvement: No improvement is needed at this time. WHC Standards Laboratory organization. program. master M\&TE equipment 1ist for use in control of the equipment.

Al1 M\&TE devices used at the 340 Facility have unique identification numbers accurately identifying the specific devices and provide positive traceabllity. A master list identifying all M\&TE is developed and kept current by the

At the 340 Facllity, there may be the need for speciallzed test and caltbration equipment. The maintenance manager and $\operatorname{cog}$ engineer review M\&TE requirements and identify the need for spectalized M\&TE. As these items are identified and their need is required, they are procured, tracked, and controiled through the existing Standards Laboratory
4.12 .2

Objective:

Discussion:

Discussion:

Discussion:

\section{Caltbration}

caltbration of M\&TE is accomplished by qualified personnel using approved procedures and standards having full traceability to the National Institute of Standards and Technology or other nationally recognized standards. standards ut 1 lized are maintained at designated controlled storage locations.

Calibration Standards

The M\&TE caltbration program is based on standards traceable to a national standard or that are recognized standards unto themselves. Traceability, administrative controls, and guidelines are in place as part of the M\&TE program. M\&TE records are maintained at the Standards Laboratory.

\section{Calibration Procedures}

Procedures are used to calibrate M\&TE, control the performance of calibrations, provide repeatable calibrations, and provide acceptance criteria.

M\&TE documentation includes records for accountability and traceability of use. A recall system is developed for recalibrations of M\&TE. This system is controlled by the Standards Laboratory. A11 M\&TE calibrations are performed through the administrative controls and requirements of the Standards Laboratory.

\section{Calibration Frequency}

A calibration frequency to maintain M\&TE accuracy and availability is established through the WHC M\&TE 
administrative program and WHC-CM-4-2 requirements. More conservative calibration frequenctes may be established by the facility.

\section{Discussion: Functional Checks}

WHC site procedures recommend M\&TE be functionally checked before use and this is performed on an as-needed basis by ICF-KH maintenance personnel.

Improvement: No improvement is needed at this time.

\subsection{2 .3}

objective:

Discussion:

Discussion:

Discussion:

Discussion:

\section{Control}

Control of M\&TE is established to ensure that equipment used to verify (calibrate) facility instrumentation operates properly.

\section{Storage}

Control of M\&TE is estabilished by WHC-CM-4-2 to ensure that equipment used to verify (calibrate) facility instrumentation operates properly. Controlled storage and issuance of calibrated M\&TE is provided at the 328 Building in the 300 Area. Any M\&TE with suspected or actual defictencies is segregated and marked to prohibit its use as required by existing site procedure.

\section{Uncalibrated M\&TE}

Any new M\&TE devices are calibrated prior to use. Control of uncalibrated M\&TE at the 340 Facility meets the requirements specified in WHC-CM-4-2.

\section{M\&TE with Limited Use}

M\&TE devices not fully calibrated or usable are either clearly marked or a copy of the callbration report is provided with the M\&TE to indicate their limitations and are only used where the limitations of the M\&TE do not affect or are within the accuracy of calibration procedure being performed.

\section{Issue and Recall}

Log IN/OUT sheets are kept for traceability by the M\&TE custodian at the 328 Building. The Standards Laboratory has administrative procedures in place for notification of calibration due dates and M\&TE recall. M\&TE usage is tracked by the maintenance department using the work request or on the calibration data sheet, if applicable. 


\section{Discussion: Cuntaminated M\&TE}

Contaminated M\&TE is controlled per existing safety and radiological guidelines at WHC. Contaminated M\&TE is not used at the 340 Facility.

Improvement: No improvement is needed at this time.

\subsection{2 .4}

\section{Evaluation}

Objective: Usage of M\&TE is controlled and evaluated to ensure proper utilization, impact/consequence of out-of-tolerance equipment use, and equipment reliability.

Discussion: Out-of-Calibration and Defective M\&TE

M\&TE devices found out of calibration or defective receive timely evaluations to determine the validity of all measurements/tests for which they were used. This is accomplished through the review of history files and controlled through the JCS PM/S program.

\section{Discussion: Performance Trending}

Results of M\&TE calibrations are trended by the Standards Laboratory. Corrective actions are determined for any M\&TE reliability problems.

Improvement: No improvement is needed at this time.

\subsection{Maintenance Tools and Equipment Control}

Methods are established to provide for storage, issuance, and maintenance of an adequate and readily available supply of tools and equipment, and for development of special tools and equipment as needed in the maintenance program.

4.13 .1

Objective:

Discussion:

\section{Storage and Issuance}

To ensure that an adequate supply of hand tools, common power tools, and equipment is readily available, properly stored, and controlled.

Overall responsibility for assuring ICF-KH has proper tools to perform 340 Facility maintenance activities, and that tools are stored properiy, is with the ICF-KH Maintenance Supervisor. Any specialized requirements are identified and steps taken to procure special tools if required. This specialized equipment is stored near the work site.

HHC-CM-4-3 and applicable ICF-kh procedures contro? the disposition of worn and defective tools. The 340 Facility 
maintenance organization works to these controls and guidelines.

Improvement: No improvement is needed at this time.

\subsection{3 .2}

Objective:

Discussion:

Improvement: No improvement is needed at this time.

\subsection{3 .3}

Objective:

Discussion:

Improvement: No improvement is needed at this time.

\section{Tool and Equipment Maintenance} are provided and scheduled as needed by ICF-KH.

\section{Use of Special Tools and Equipment} and equipment. appropriate work packages.

Tools and support equipment are included in the preventive maintenance program to maintain a safe use condition and to provide necessary care to maintain its service life.

Condition of tools is monitored by the user; tools are repaired/replaced as is deemed necessary. Preventive maintenance procedures for inspection of specific tools

Special tools and equipment are available and are clearly marked for their intended use. Work packages include necessary instructions for the proper use of special tools

Special tools, test rigs, special equipment, lifting and rigging equipment, and mockups required for maintenance activities at the 340 Facility are identified in the

Specific instructions are provided to control the use of lifting and rigging equipment in DOE-RL-92-36, "Hanford Site Hoisting and Rigging Manual". The 340 Facility maintenance organization abides by these guidelines.

\subsection{Facility Condition Inspection}

Management conducts periodic inspections of equipment and facilities to assure excellent facility condition, housekeeping, and safe and reliable operation.

\subsection{4 .1}

Objective:

\section{Standards}

Management conducts periodic inspections of equipment and facilities to assure excellent facility condition and housekeeping. The condition of a facility is dependent on many factors, including design, fabrication, modification, ongoing maintenance, the facility work control programs, and day-to-day operation. After initial facility construction, ongoing maintenance and the control of modifications are prime contributors to keeping systems 
and equipment in optimum condition to support safe and reliable operation.

Discussion: 340 Facility Operations, Engineering, and Maintenance Managers perform inspections of the 340 Facility on a regular basis to ensure standards are maintained.

Managers set achievable facility condition and housekeeping standards, given the 42-year age of 340 Facility, and communicate them to all personnel to provide a clear understanding of these standards.

Improvement: No improvement is needed at this time.

\subsection{4 .2}

Objective:

Discussion:

Improvement: No improvement is needed at this time.

\section{Training} inspections and condition reporting. WHC-IP-1000.

Personnel involved in facility inspections receive instructions to establish knowledge of standards and related facility policies. Methods for determining condition status are provided for consistency of

The 340 Facility Operations Manager is responsible for communicating inspection criteria and techniques required to perform facility condition inspections as directed in

\subsection{4 .3}

objective:

Discussion:

Improvement:

\subsection{4 .4}

Objective:

\section{Procedures}

Procedures are provided defining the facility inspection prograrl, methods of implementation, standards of condition, and means for correction of deficiencies found. Deficiencies found are evaluated for changes to the facility maintenance program.

Facility inspections and housekeeping requirements are defined in WHC-IP-1000. Housekeeping inspections are conducted by the Facility Manager and the Operation Manager. Housekeeping deficiencies are brought to the attention of shift operations managers, who then resolve deficiencies as appropriate.

No improvement is needed at this time.

\section{Scope of Inspections}

Inspections include detailed walkdowns of assigned areas that include remote and limited-access areas as well as the more obvious and available areas. Key individuals are included in the inspection teams with free discussion of technigues and concerns encouraged. Sufficient time is allowed to search for deficiencies rather than a quick 
walk through. Obvious deficiencies are investigated to the degree necessary to positively identify the source of the problem.

Discussion: Facility condition inspections are currently conducted as part of Safety Council inspections, manager surveillances, and routine work site housekeeping control. In all cases inspections are probing in nature, with the specific intent of looking beyond the obvious. The 340 Facility Manager is responsible for ensuring all 340 Facility areas and buildings are inspected on a regular basis.

Improvement: No improvement is needed at this time.

\subsection{4 .5}

\section{Inspection Program Elements}

Objective: Inspection assignments are scoped to ensure adequate time for thorough inspection and scheduled to minimize impact to ongoing operations of the facility.

Discussion: Current inspection schedules are established with sensitivity to the inspection team availability and facility schedules. Adequate time is allocated to perform thorough inspections and initiation of reports. The 340 Facility maintenance program uses existing WHC programs and policies.

Improvement: No improvement is needed at this time.

\subsection{4 .6}

\section{Reporting Deficiencies}

Objective: Deficiencies noted during inspection are entered into the work control program for corrective action. Significant and/or safety related deficiencies are assigned the appropriate priority and reported to the responsible facility manager. Housekeeping deficiencies are reported to the occupying organization for attention.

Discussion: Deficiencies noted are documented and entered into the existing work control system. Severity and priority of deficiency is assigned based on existing administrative procedures and work is scheduled accordingly.

Inorovement: No improvement is needed at this time.

\subsection{7}

Objective:

\section{Deficiency Follow-up}

Reported deficiencies are monitored for timely completion of corrective actions. Recurring, generic, or long term problems are analyzed for identification of root cause. Recommendations are provided for changes to the preventive maintenance program. Periodic evaluation of inspection reports and facility conditions are made to determine program effectiveness. 
WHC-SP-1154

Revision 0

Discussion: Tracking of reported deficiencies is accomplished, as appropriate, by the Hanford Action Tracking System (HATS, company-wide), the Action Management. System (AMS, division-wide), or the Commitment Tracking System (CTS, within 300 Area LEF). Priority assignment is monitored in relation to other outstanding, work requests to ensure attention is given to the appropriate work, per the graded approach philosophy.

Improvement: No improvement is needed at this time.

\subsection{Management Involvement}

To ensure the safety of DOE facility operations, DOE and contractor corporate and facility managers are sufficiently involved with facility operations to be technically informed and personally familiar with conditions at the operating facility.

\subsection{5 .1}

Objective:

Discussion:

$$
\text { pa }
$$

The 340 Facility Maintenance Manager walks through
Facility on a routine basis. This walk-through is
performed to improve face-to-face communication and feedback at ail levels of maintenance, to set standards for facility condition and housekeeping, and to assess work load. Identified deficiencies are reported and corrected in a timely manner so personnel can see the positive results of the inspection program.

\section{Management Involvement}

Management conducts periodic inspections of equipment and facilities to assure excellent facility condition and housekeeping. The condition of a facility is dependent on many factors, including design, fabrication, modifications, ongoing maintenance, the facility work control programs, and day-to-day operation. After initial facility construction, ongoing maintenance and the contral of modifications are prime contributors to keeping systems and equipment in optimum condition to support safe and reliable operation.

The involvement of facility managers and supervisors in periodic facility walkdowns and inspections clearly displays management standards to all personnel and can significantly improve the condition of the facility. A program for identification and disposition of facility condition deficiencies and housekeeping discrepancies is an important step in maintaining facilities and equipment in a condition of maximum safety, reliability, and availability.

No improvement is needed at this time. 
4.15 .2

Objective:

Discussion: ut 17 ized throughout 300 Area LEF. Specific maintenance indicators are tracked monthly via the 340 JCS Performance Indicator Package. Trending data is an integral part of this package.

Improvement: No improvement is needed at this time.

\subsection{5 .3}

objective:

Discussion:

\section{Feedback}

Feedback systems are in place to provide means for continuous communications between all groups, worker disciplines, and management levels. Methods are in place to apply lessons learned from experiences of others, and in-house, to ensure long-term success. All levels of management are available to discuss problem areas ard suggested improvements.

Feedback systems are in place through all-employee meetings and monthily safety meetings, and group staff meetings. Management expectations are conveyed to a 11 levels of the organization. 340 Facility Management follows an open door policy enabling maintenance personnel to have direct access to management when concerns are present. Employees may use the chain of command and/or an appeals board to voice any concerns. An in-house lessons learned program is in place and actively utilized.

Improvement: No improvement is needed at this time.

\subsection{5 .4}

Objective:

\section{Program Reviews}

Managers periodically review and assess all elements of the maintenance program to identify areas requiring improvement or corrective action. Input of managers and supervisors, and other supporting organizations, is utilized in program review. Areas requiring improvement are assigned for corrective action and follow-up.

Discussion: At 340 Facility the Maintenance Manager follows a program of reviews and self assessments on an as-needed basis and per the requirements of WHC-IP-1000. Feedback from self assessments and reviews determines maintenance organization policy changes. 
WHC-SP-115A

Revision 0

\section{Discussion: Assessment of Facility Condition and Worker Practices During Maintenance}

Periodic assessments of specific programs such as the $\mathrm{PM} / \mathrm{S}$ program are performed per site procedure. 340 Facility specific program evaluation is provided by the Maintenance Manager as the need for such an evaluation becomes apparent through audits and assessments.

The 340 Facility Manager and ICF-KH Maintenance Supervisor periodically review personnel performance and work practices. This review is directed at improving worker performance. Appraisals are performed in accordance with WHC and ICF--KH company poitcies.

Equipment and component maintenance history is trended through the application of the JCS program. The cog engineer reviews this history for maintenance trends or problems.

\section{Discussion: Assessment of Maintenance Training}

The maintenance organization periodically reviews the maintenance training program (WHC-IP-1000) specifically as to 340 Facility impact. Results of this review dictate the need, or lack there of, for training program enhancements and changes.

Discussion: Assessment of Procurement Activities

Assessments of the procurement process are performed as needed by facility operations and maintenance management for timeliness and responsiveness.

Discussion: Assessment of Measuring and Test Equipment

Facility management assesses the availability of M\&TE to support safe and reliable 340 Facility operations.

Improvement: No improvement is needed at this time.

\subsection{Maintenance History}

A maintenance history and trending program is maintained to document data, provide historical information for maintenance planning, and suprort maintenance and performance trending of facility systems and components.

4.16 .1

Proyram Development

Objective: A program is in place identifying critical (from the $S A D$ ) systems and equipment requiring documentation and retention of historical data. 
WHC-SP-1154

Revision 0

Discussion: Equipinent Identification

The SEL provides the identification for major or critical pieces of equipment. Maintenance history, where required, is provided through the work history module of the JCS.

Discussion: Data Identification

Completed work packages under the JCS program include all relevant maintenance data for a given critical piece of equipment. Specific data requirements for a given piece of 340 Facility equipment not previously identified are provided by the cog engineer.

Improvement: No improvement is needed at this time.

4.16 .2

Data Collection

Objective: Information for systems and equipment identified for record history retention is forwarded to a specified organization for control, reviewed for completeness and correctness, and entered into the equipment history program. Records are maintained as specifled in WHC-CM-3-5.

Discussion: Data on 340 Facility systems and equipment selected for history retention is controlled through the JCS PM/S and work history modules, or by data input directly to the cog engineer for analysis and trending.

Improvement: No improvement is needed at this time.

4.16 .3

\section{Program Use}

Objective: Equipment history data is readily avallable to all organizations and is used in the devalopment of work packages and schedules, and is periodically reviewed for developing trends.

Discussion: The JCS program establishes a maintenance history program. This program is reviewed by the facility munagers, cog engineers, or any personnel involved with 340 Facility maintenance to identify problem areas or areas where maintenance activities are unnecessary.

Improvement: No improvement is needed at this time.

\subsection{Analysis of Maintenance Problems}

Systematic analysis is used to determine and correct root causes of unplanned occurrences related to maintenance. 


\subsection{7 .1}

objective:

Discussion:

Improvement: No improvement is needed at this time.

\subsection{7 .2}

Objective:

Discussion: Improvement: No improvement is needed at this time. factors are identified and categorized.

\section{Information collection}

In preparation of event analysis, all applicable logs, records, recordings, and personnel, interview statements are gathered.

When a significant equipment fallure, off-normal operating event, or personnel accident occurs, every effort is made to preserve physical conditions, obtain first hand observations and interviews, and to obtain a 11 associated documentation relating to the event. Event report requitrements and responsibilities are defined in WHC-IP-1000.
Action Management Manua 7. Activities required for event analysis are performed in accordance with this procedure and guidelines in WHC-IP-1000.

In performing an event analysis a detailed sequence of facts and activities is developed and apparent causal

Root cause analysis is addressed in WHC-CM-1-4. Corrective

\subsection{7 .3}

\section{Cause Determination}

Objective: Actual or probable causes of a problem are evaluated by one or more techniques to establish a final root cause. Appropriate documentation is developed to ald in the analysis, to record analysis performed, and to document corrective action recommendations.

Discussion: Root cause analys is is addressed in WHC-CM-1-4. Activities required for cause determination are performed in accordance with this procedure and guidelines in WHC-IP-1000.

Improvement: No improvement is needed at this time.

\subsection{7 .4}

\section{Corrective Action}

Objective: Corrective action plans are developed, initiated, and tracked to completion. Plans address all applicable activities such as repairs, preventive maintenance procedures, and personnel training.

Discussion: Once root cause analysis has been performed, corrective action is determined and initiated in accordance with WHC 
site procedures. Corrective ictions are tracked via the HATS, AMS, or CTS, as approprtate.

Improvement: No improvement is needed at this time.

\subsection{7 .5 \\ Corrective Action Follow-up}

Objective: Corrective action follow-up activities include specific post repair testing and continued monitoring of equipment as positive means to ensure corrective actions taken in fact resolve the problem experience.

Discussion: Per the JCS, post-maintenance testing requirements are defined, included in corrective action work packages, and tracked. Monitoring of equipment continues at the previous level unless specific associated changes are directed. Procedural or administrative changes are followed by the 340 Facility Operations and Maintenance Managers and the training organization.

Improvement: No improvement is needed at this time.

\subsection{7 .6}

Objective:

Discussion:

\section{Genertc Follow-up}

Analysis program includes considerations of generic corrective actions needed for equipment of the same make and model.

The cog engineer is responstble for reviewing follow-up actions for impact to other similar or same type equipment at the 340 Facility. The cog engineer identifles any required action or rework.

Additional follow-up of root cause efforts enhancing future analysis is performed in accordance with existing WHC site procedures.

Improvement: No improvement is needed at this time.

\subsection{Modification Work}

Facility modification work, including temporary modifications, is accomplished under the same basic administrative controls as those applied to facility maintenance activities so there is no increases in risk to factlity equipment, environment, or personnel because of the modifications work.

4.18 .1

\section{Maintenance Program Interface with Modifications}

Objective: Modifications are performed in accordance with requirements and iimitations of applicable procedures, codes, standards, and specifications. 
Discussion: Modiflcation work performed by ICF-KH maintenance persunnel at the 340 Factlity is in conformance with the requitrements of $W H C-C M-6-1$, WHC-CM-1-8, and app 1 tcable ma intenance procedures.

Improvement: No improvement is needed at this time.

4.18 .2

Temporary Repalrs or Temporary Modifications

Objective:

Temporary repairs or modiftcations are reviewed in accordance with the factlity modification program prior to implementation. Temporary repairs or modifications are tracked after completion for consideration of permanent corrective action.

Discussion: Temporary repalrs and temporary modifications are controlled per the procedural requirements of WHC-CM-6-1 and WHC-IP-1000 and are tracked by the JCS to completion.

Improvement: No improvement is needed at this time.

\subsection{Additional Maintenance Management Requirements}

A program is in place to prevent equipment and buflding damage due to cold weather at any nuclear facillty that may be at risk.

4.19 .1

Objective:

\section{Seasonal Facility Preservation Requirements}

Cold weather protection program in place to ensure continued safe facllity operations is defined and implemented using approved procedures. Program includes criterta for preparation (and suspension), pertodic survelliances, and program effectiveness evaluations. Lessons learned are evaluated and appropriate program changes made to prevent recurrence.

Discussion: Seasonal freeze protection at 340 Facility is performed in accordance with WHC-CM-8-7, Cold Weather Protection, and Maintenance Procedure 7-GN-107, Cold Weather Protection. Winterization and de-winterization $P M / S$ procedures exist for affected 340 Facility equipment.

Improvement: No improvement is needed at this time. 
WHC-SP-1154

Reviston 0

\subsection{DEVIATIONS REQUESTED WITH SUPPORTING RATIONALE}

No deviations from the poltcy requirements identified by DOE Order 4330.4B (DOE 1994) are requested at this time. 


\subsection{IMPLEMENTATION SCHEDULE}

The following is the schedule of activities that are to be accomplished before the next re-assessment of the 340 Facility MIP at the spe-ified two-year interval. The activities identifled are based upon assessmen: at the time of the writing of this document. This schedule may be changed, based on further maintenance activity assessments.

\begin{tabular}{|c|c|c|c|c|c|c|c|c|c|c|c|c|c|}
\hline \multirow{2}{*}{ ACTIVITY } & \multicolumn{4}{|c|}{95} & & \multicolumn{4}{|c|}{96} & \multicolumn{4}{|c|}{97} \\
\hline & & 2 & 3 & & & 1 & 2 & 3 & 4 & & 2 & 3 & 4 \\
\hline $\begin{array}{l}\text { 4.5.1 Master Equipment List } \\
\\
\text { Develop } 34 \text { P Factl I Iy Master }\end{array}$ & & & & & & & $x$ & & & & & & \\
\hline
\end{tabular}


WHC-SP-1154

Reviston 0

\subsection{BIBLIOGRAPHY}

DOE, 1994, Maintenance Management Program, DOE Order 4330.4B, U.S. Department of Energy, Washington, D.C.

DOE, 1991b, Qualyty Assurance, DOE Order 5700.6C, U.S. Department of Energy, Washington, D.C.

DOE, 1991a, Accreditation of performance-Based Training for Category $A$ Reactor and Nuclear Facilities, U.S. Department of Energy, Washington, D.C.

DOE, 1993, DOE-RL Hanford Site Hoisting and Rigging Manual, DOE-RL-92-36, U.S. Department of Energy, Richiand, Wa.

DOE, Hanford Site Radiological Control Manual, HSRCM-1, U.S. Department of Energy, Richland, Wa.

WHC, 7-GN-107, Cold Weather Protection, Westinghouse Hanford Company, Richland, Washington

WHC, OSD-SW-153-00001, Operating Specification Document for the 340 Waste Handling Facility, Westinghouse Hanford Company, Richland, Washington

WHC, SD-WM-SEL-016, 340 Facility Safety Equipment List, Westinghouse Hanford Company, Richland, Washington

WHC, SD-WM-TM-001, Safety Assessment Document for the 340 Waste Handling Facility, Westinghouse Hanford Company, Richland, Washington

WHC, WHC-CM-1-4, Corrective Action Management Manual, Westinghouse Hanford Company, Richland, Washington

WHC, WHC-CM-1-8, Work Management Manua7, Westinghouse Hanford Company, Richland, Washington

WHC, WHC-CM-2-1, Procurement Manual and Procedures, Westinghouse Hanford Company, Richland, Washington

WHC, WHC-CM-2-2, Materia7s Management Manua7, Westinghouse Hanford Company, Richland, Washingtion

WHC, WHC-CM-2-15, Training Administration Manual, Westinghouse Hanford Company, Richland, Washington

WHC, WHC-CM-3-5, Document Control and Records Management Manual, Westinghouse Hanford Company, Richland, Washington

WHC, WHC-CM-4-2, Quality Assurance Manual, Westinghouse Hanford Company, Richland, Washington

WHC, WHC-CM-4-3, Industria7 Safety Manual, Westinghouse Hanford Company, Richland, Washington 


$$
\begin{gathered}
\text { WHC-SP-1154 } \\
\text { Revision } 0
\end{gathered}
$$

WHC, WHC-CM-6-1, Standard Engineering Practices, Westinghouse Hanford Company, Richland, Washington

WHC, WHC-CM-8-7, Cold Weather Protection, Westinghouse Hanford Company, Rich and, Washington

WHO, WHC-IP-1000, 300 Area Liquid Effluent Facilities Administration, Westinghouse Hanford Company, Richland, Washington

$7-2$ 
WHC-SP-1154

Revision 0

\section{DISTRIBUTION}

\section{Number of Copies}

\section{Onsite}

8

U.S. Department of Energy,
Richland Operations Office
J. M. Augustenborg (3)
S7-55
A. V. Beard
S7 -55
E. M. Bowers
S7-55
B. E. Hill
R3-78
J. D. Voice
S7-41
Public Reading Room
A1-65
MAC Technical Services Company

1

B. A. Davis

R3-82

21

Westinghouse Hanford Company
J. R. Barber
S4-65
L. D. Berneski
L6-04
A. J. Diliberto
H6-10
D. L. Halgren
L6-04
E. R. Hamm
S4-64
G. L. Kunkle
L.4-96
D. W. Lindsey
L6-04
L. W. Roberts
F. N. Wagner (8)
L6-05
L4-96
E. J. Wright
L4-96
Central Files
L8-04
EDMC
H6-08
Information Release
Administration
L8-07
OST I
L8-07 

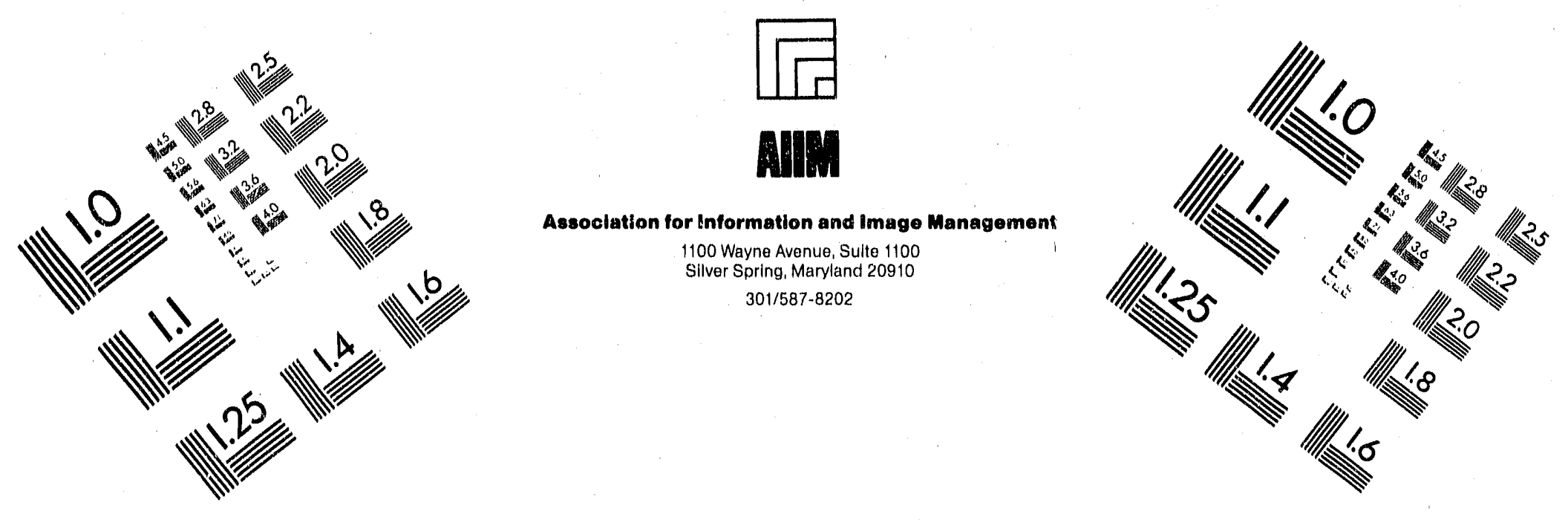

Centimeter

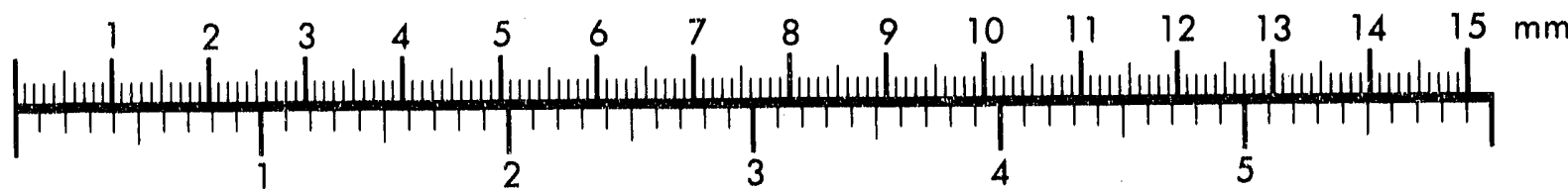
Inches
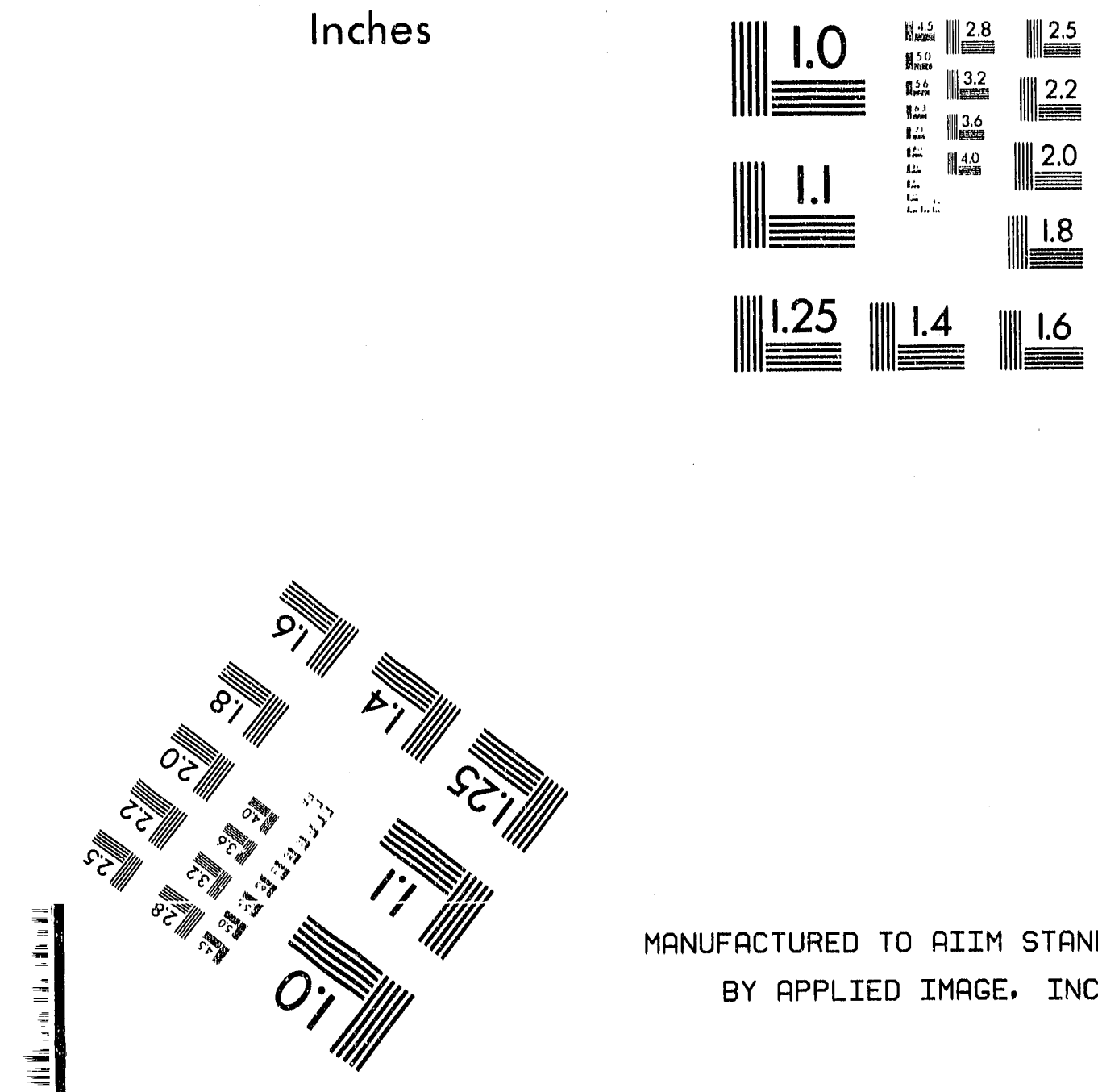

MANUFACTURED TO AIIM STANDARDS

BY APPLIED IMAGE, INC.

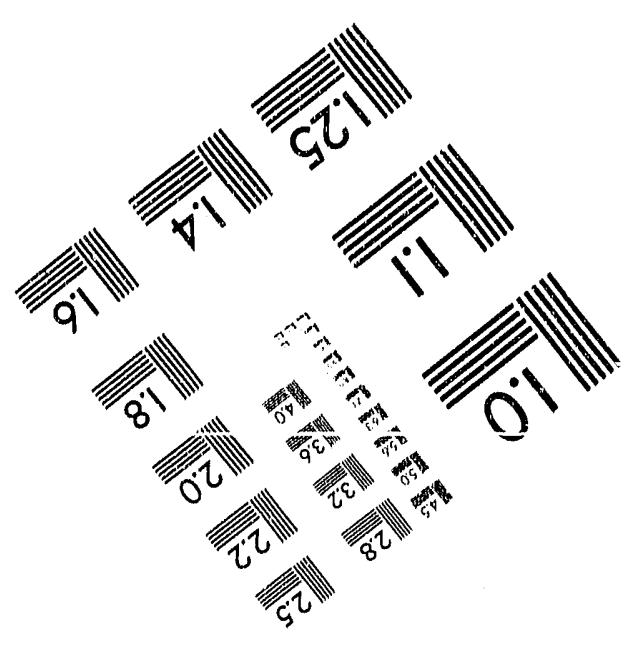



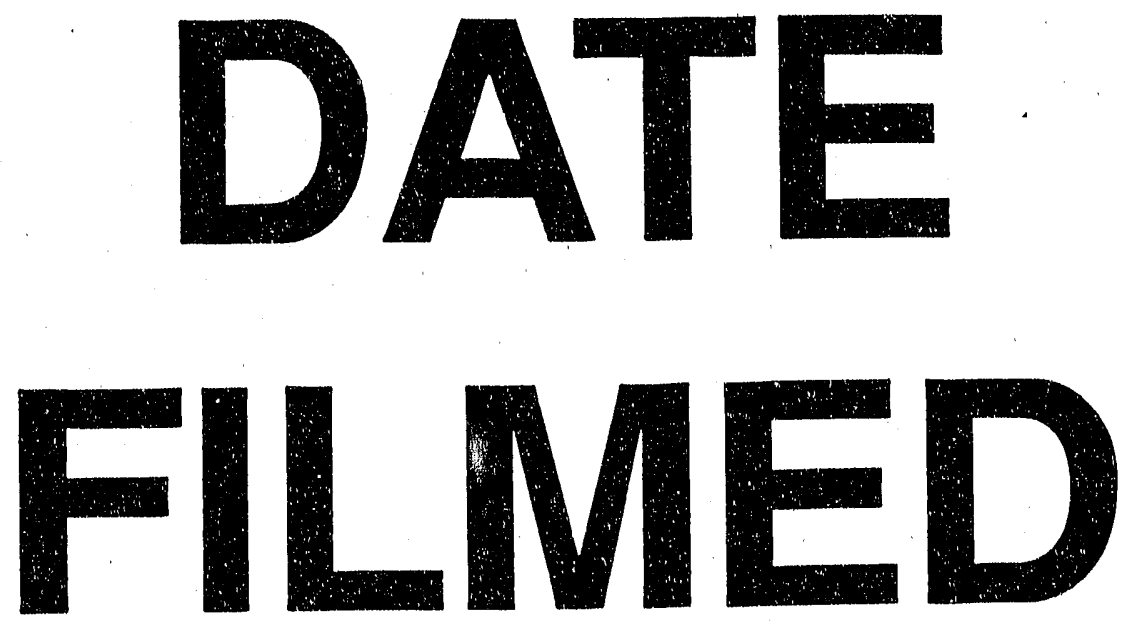

$6 / 22 / 95$
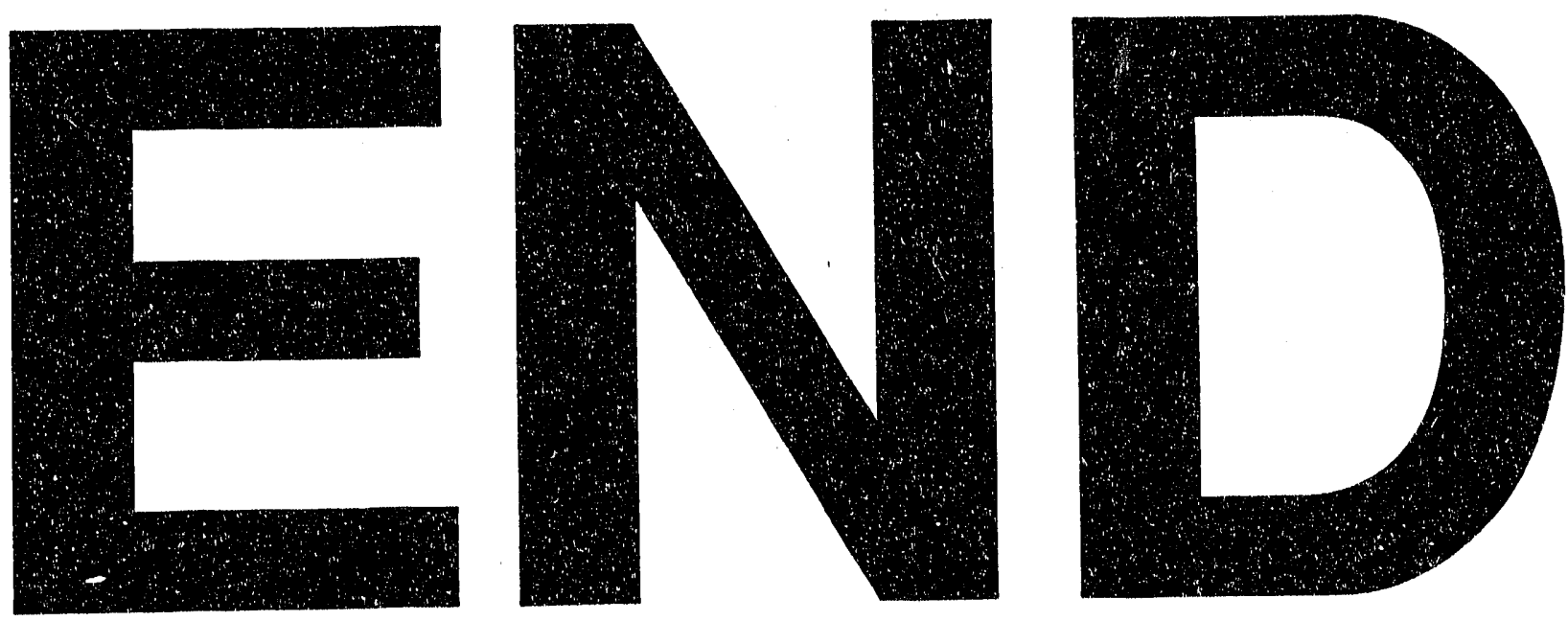